\title{
Beyond Slacktivism: The Cases of K-pop Fans and Tiktok Teens
}

\author{
Tara Shafie \\ Irvine High School \\ 4321 Walnut Ave, Irvine, CA 92604 \\ E-mail: tshafie117@gmail.com
}

Received: July 2, 2021 Accepted: August 4, 2021 Published: August 10, 2021

doi:10.5296/ijssr.v9i2.18924ＵRL: https://doi.org/10.5296/ijssr.v9i2.18924

\begin{abstract}
With recent technology and social media, new forms of political activism have become widespread. Young people in particular, have been willing to embrace these new forms of activism. This paper examines new trends in digital activism through qualitative observations of Twitter and Tiktok, and three case studies of young people's digital activism. In the first case study, Korean pop music (K-pop) fans thwarted police's attempts to identify protesters by crashing police apps. In the second, they rendered white supremacist hashtags useless, by drowning out the hashtags with their own tweets. Finally, K-pop fans, along with Tiktok users, played a prank which humiliated the Trump reelection campaign. The study expands upon the life cycle effect and generational effects theories of political behavior, and develops a continuum with which to conceptualize and understand the nature of activism. It concludes that digital activism is characteristic of Gen Z, and has real-world impacts. This article pushes back on the notion that digital activism is mere "slacktivism" (low effort token support of a social movement). Instead, it argues that activism evolves along with technology and time, and that digital activism's real-world impacts can be just as effective as conventional political activism.
\end{abstract}

Keywords: slacktivism, k-pop, tiktok, gen z, digital activism 


\section{Introduction}

As technology continues to develop, aspects of society develop along with it. Political activism is no exception to this. Technology has made it possible to be politically active online, especially with social media. Digital political activism has been readily embraced by young people, who are particularly attuned to technology, having grown up with it. This paper focuses on digital activism, paying particular attention to Twitter and Tiktok users. Due to recent events, digital activist movements such as \#BlackLivesMatter are stronger than ever before. These movements have prompted a new outlet for activism via the internet, utilized by young people as an alternative to conventional participation.

However, digital activism has been dismissed as mere "slacktivism," (low effort token support of a social movement) to which this paper offers a corrective for those earlier conceptions. As shown in recent research, young people (pp. 18-24) tend to be less conventionally politically active than older people. But, as trends show, they also favor more unconventional forms of political activism, such as digital activism. This paper examines new trends in digital activism through qualitative observations of Twitter and Tiktok, and three case studies of young people's digital activism. In the first case study, Korean pop music (K-pop) fans thwarted police's attempts to identify protesters by crashing police apps. In the second, they rendered white supremacist hashtags useless, by drowning out the hashtags with their own tweets. Finally, K-pop fans, along with Tiktok users, played a prank which humiliated the Trump reelection campaign.

The present study expands upon the life cycle effect and generational effects theories of political behavior. These theories are applied to analyze Gen Z's (Note 1) growing political impact. The paper also develops a continuum with which to conceptualize and understand the nature of activism. It finds that examples of digital activism can be just as impactful as conventional activism. Different forms of activism, both conventional and unconventional, are compared based on level of effort, and level of impact. I conclude that digital activism is characteristic of Gen Z, and has real-world impacts.

\section{Literature Review}

As we will see in the following literature review, recent research shows both the history of digital activism, and the activism styles of younger people. One notable type of digital activism is hashtag activism. Hashtags can be comprised of multiple words, or even be as little as one letter, but by adding the hashtag symbol to the front of a phrase or word, it is easier to search for on platforms such as Twitter. An example of hashtag activism is \#BlackLivesMatter. BLM originally began in 2013 from a Facebook post, after the death of Trayvon Martin (Yang, 2016). The hashtag then spread across other platforms, and became a movement. The movement gained momentum in 2020, after the death of George Floyd. By posting and tweeting, activists can get their messages to a much wider audience than even ten years ago, when social media was not as widespread. This usage of civic media in terms of both political and social activism is now a "routine" part of protest movements (Jenkins et al., 2016). This has been seen from the Arab Spring, to the Occupy movement, Hong Kong protests, and to BLM, where activists used social media to organize, discuss, and spread their messages (De Choudhury et al., 2016). 
Most studies on political activism of young people focus on conventional activism, and generally conclude that young people are less politically active (Plutzer, 2002; Holbein \& Hillygus, 2015). For example, the voter turnout for young people, ages 18 to 24 in the United States, is 20 percent lower than the electorate as a whole (Aldrich et al., 2020). A similar 20 percent gap can be seen among voters in the European Union (Fieldhouse et al., 2007). However, while young peoples' conventional civic and political engagement may be lower than generations before, they instead prefer more unconventional types of activism and civic engagement, such as "creating and circulating photos, memes, and videos to their networks", as well as protests and volunteerism (Cho et al., 2020). One study found that girls in particular prefer using social media for political activities, as opposed to typically adult run, in-person organizations (Keller, 2012). However, this type of activity has been dismissed as mere "slacktivism". Slacktivism has been defined as "...a willingness to perform a relatively costless, token display of support for a social cause, with an accompanying lack of willingness to devote significant effort to enact meaningful change" (Kristofferson et al., 2014). Another term for "slacktivism" is "clicktivism" which emphasizes activities such as liking, upvoting, and following (George \& Leidner, 2019). The notion of "slacktivism" is used to ridicule the mostly young activists. One observer described it as:

"...the ideal type of activism for a lazy generation: why bother with sit-ins and the risk of arrest, police brutality, or torture if one can be as loud campaigning in the virtual space? Given the media's fixation on all things digital - from blogging to social networking to Twitter-every click of your mouse is almost guaranteed to receive immediate media attention, as long as it's geared towards the noble causes" (Morozov, 2009).

Rather than being lazy, however, digital activism is an updated form of political activism with real-world impact. As times and technology change, so does activism. For people who are too young to do more conventional types of activism, such as voting, digital activism is among the only type of activism that they can do. For example, if a teenager's parents will not let them go to a protest, that does not mean the teenager is lazy. Instead of attending a protest, a teenager might post on their social media platform to contribute in any way they can. Although there is a possibility of people participating in digital activism for the sole purpose of clout and media attention, that is not true of the majority. Labelling an entire generation as "lazy" because they utilize newer technology for their activism is incorrect.

Two theories that help us understand why different age groups gravitate toward different types of activism are the life cycle effect theory (also called life course theory), and the generational effects theory. These theories have been applied to public opinion and political behavior. I will examine each in turn. The life cycle effect states that as people grow older, they will develop more of an attachment to their community, and thus participate in politics more actively compared to when they were younger (Aldrich et al., 2020; Braungart \& Braungart, 1986). Through the four major stages in life: childhood, youth, middle age, and older adulthood, patterns can be identified regarding political behavior (Braungart \& Braungart, 1986). In childhood, children are aware of political symbols, but do not understand politics itself very well, and are influenced by their parents' political beliefs. More complex concepts such as government begin to be understandable during later childhood, as well as partisan loyalty. 
During youth, cognitive changes occur that "set the stage for greater political awareness," (Braungart \& Braungart, 1986). People also become critical of society and their elders at this stage, and begin to form their own beliefs in addition to the ones they were raised with. Middle aged people are more likely to vote and participate in conventional politics as opposed to younger people. This is due to the power that they hold in both society and politics. In older adulthood, people are even more likely to vote than in middle age. As the theory states, people's participation in politics will increase with age.

The generational effects theory explains variations in policy preferences and political behavior by focusing on events that define a generation, such as the Great Depression, the Vietnam War, and 9/11. These types of events have a profound impact on youth who become politically aware in their teens and early 20's, and will go on to shape members of that generation's politics. There are three types of generational politics: lineage politics, cohort politics, and political generations (Braungart \& Braungart, 1986). Lineage politics are the political ideologies that are passed down throughout each generation in a family, which leads to children often sharing their parents' political beliefs. Cohort politics refers to a group of people of similar age, and similar political ideologies. Finally, cohort politics will develop into the third type of generational politics, a political generation, when people of the generation "mobilize as an active force for political change" (Braungart \& Braungart, 1986). With the aforementioned political and social events that define a generation, political activism will develop in response. During the Great Depression, the Silent Generation voted. During the Vietnam War, the Baby Boomer generation protested. In the years after $9 / 11$, however, social media began to become widespread. Social media then became a way to be politically active, in addition to voting and protesting. The newer digital activism is just as effective as conventional activism, as shown in the cases of K-pop fans and Tiktok teens for social justice. I will now examine how these cohorts were formed, and later became politically active.

\section{Understanding K-pop Twitter}

Here, I look at how Korean pop music (K-pop) fans use social media, and how they got involved with politics. As shown in the first two case studies, K-pop fans use videos called "fancams". To understand the role of these videos in the case studies, we must first examine the nature of fancams. Fancams are often a fan-shot video of a particular K-pop idol performing, as opposed to the whole group, or a shot of the entire stage. The camera follows the idol around to get a good view of the idol's full performance. Fancams are typically shot by fansites, who are mostly Korean fans that take high-quality pictures and videos of certain K-pop idols. Since the rise in popularity of these fancams, however, official TV programs have begun to film their own "fancams" when idols perform on their shows.

The popularity of fancams is attributed to one particular video of K-pop girl group EXID's member Hani, performing their song "UP\&DOWN". Published on October 9th, 2014, the video has since accumulated over 31 million views. Fans were captivated by her individual performance, and began to copy that format of a vertically shot video of one idol, so that they could admire their favorite idol's individual performance as well, which official stages do not show. 
In addition to showing the talent of a particular idol, fancams have multiple uses. The presence of fancams on Twitter began when fansites uploaded the videos they took, and when users uploaded fancams that were previously published on YouTube. To K-pop fans, inserting a fancam into the end of their tweets is something so normal and ingrained in their fan culture. Most of the time, K-pop fans will tweet a certain fancam to increase views on it. Many fancams have accumulated millions of views because of fans that work hard to get the video more views. Certain tactics they use to increase views on their fancams include: posting a fancam with a trending hashtag in the tweet, inserting a fancam in a reply to a tweet, and tweeting a provocative message to get a rise out of other users, which will ultimately lead to more engagement with the tweet. The original intention behind fancams on Twitter was to increase the views of the videos, but as K-pop fan culture on Twitter developed, the usage of fancams became second nature to fans. Oftentimes, K-pop fans will post fancams just to make other non-K-pop fans mad, and that is what helped earn K-pop fans a bad reputation on Twitter. That is why it was such a shock to many people that K-pop fans stopped trolling people for views on their fancams, and instead used their numbers and collective influence to fight for social justice.

\section{Teenagers on Political Tiktok}

The Chinese app "Tiktok" rose to popularity in the United States around late 2018, and gained even more traction in the following years. With over 800 million users, $41 \%$ are between the ages of 16 and 24 (Mohsin, 2020). Many teenagers and young adults use Tiktok because it is reminiscent of the app Vine, which shut down in 2017. Vine was an app owned by Twitter which allowed users to make 6-second-long videos. Tiktok, however, will let you shoot up to 59 -second videos. Many trends and jokes in Gen Z originated from Vine, and now recent ones originate from Tiktok. When a user launches the app, they are taken to the "For You" page, which consists of videos the algorithm believes the user will enjoy. The algorithm will accommodate based on the hashtags in the description of videos the user watches, and the videos on the For You page will change. Examples of such hashtags include: \#dance, \#anime, and \#politics. People who enjoy a certain topic will hashtag their videos appropriately, so that more people can view their videos if they are also interested in the subject. The algorithm and hashtags have led to cohorts of people with common interests. The cohort that this paper will observe is "political Tiktok". There are many subgenres of political Tiktok, such as liberal Tiktok, and conservative Tiktok. The messages and calls to action covered in the third case study of this paper were spread through political Tiktok, or liberal Tiktok in particular. Teenagers on Tiktok were able to mobilize easily with the help of the Tiktok algorithm, which put key videos on many users' For You pages. The mobilization of the generally young political Tiktok cohort against the Trump Campaign could also be seen as the beginning of a political generation, according to the generational effects theory.

\section{Methods}

For my research, I used both Twitter advanced search, and Tiktok search. On Twitter, I searched for keywords and hashtags over a certain time period. For further hashtag analysis, I used the program Keyhole, which gave me figures for hashtags over the course of an entire 
month. I then collected screenshots (Note 2) of specific tweets for examples, as well as transcribed them. I also transcribed Tiktok videos.

\section{Case Study: Thwarting Police Efforts to Identify Protesters}

The first of three instances of K-pop fans and Tiktok users fighting for social justice that this paper will cover, is the crashing of the Dallas Police Department's app. On May 30th, 2020 the Dallas Police Department tweeted, "If you have video of illegal activity from the protests and are trying to share it with @DallasPD, you can download it to our iWatch Dallas app. You can remain anonymous," following major protests about racial injustice, and the death of George Floyd. The Police Department encouraged people to submit videos of protesters so that they could be found and arrested. However, to protect the identities of the protesters, as well as give the police a hard time, K-pop fans began to flood the iWatch app with fancams. The original tweet calling the K-pop fans to action was by user @ygshlt a day later, stating, "guys download the app and (expletive) FLOOD that (expletive) with fancams make it SO HARD for them to find anything besides our faves dancing." Accumulating over 40.9k retweets and $105.2 \mathrm{k}$ likes, the message to all the K-pop fans on Twitter was heard. Two hours after the tweet was posted, the iWatch app was down "due to technical difficulties" according to a tweet by the Dallas Police Department. The app was, in fact, overloaded with the amount of fancams that had been submitted, effectively protecting the protesters from usage of the app. Among many tweets about submitting fancams to the app, user @ash_the_oddball tweeted, "me sending "TAEMIN [SEXY] TAKING OFF HIS JACKET - FANCAM" to the dallas police department because (expletive) exposing protestor's faces." This method of obstructing police activity to protect protesters with fancams was replicated on May 31 st, after the Grand Rapids Police Department tweeted that they "set up a portal so you may upload any picture or video evidence you have from last night's unrest". On June 1st, user @ngelwy tweeted, "you know the drill! SEND IN ALL OF YOUR FANCAMS!!! CRASH THE WEBSITE!!! MAKE THEM TAKE IT DOWN!!! PROTECT THE PROTESTERS!!!” That tweet accumulated over 45.2k retweets, and $123.9 \mathrm{k}$ likes, and two days after the portal was set up, it was closed.

Police have used facial recognition software to identify protesters in the past (Miller, 2020). To be clear, K-pop fans were not flooding the apps to protect the people who had been looting, but to protect the actual protesters. This was done to prevent any possible police harassment against innocent people. K-pop fans had reason to believe that the police would possibly arrest people who were not even involved in the protests, based on past incidents, as Baltimore police had done in 2015 (Marketplace Tech). With mass surveillance and facial recognition, the police are capable of finding and charging people who were simply in the vicinity of the protest. This is why it was imperative to prevent any outlets of evidence from being used, thus, the apps were crashed.

\section{Case Study: Rendering White Supremacist Hashtags Useless}

The second case study, is the drowning out of white supremacists by K-pop fans on Twitter. In response to June 2nd's \#BlackOutTuesday, a hashtag created to raise awareness of BLM, as well as racial injustice, white supremacists advocated for the trending of \#WhiteOutWednesday on June 3rd. In addition to \#WhiteoutWednesday, the hashtag 


\section{Macrothink}

\#WhiteLivesMatter was also created to detract from BLM. These two hashtags began to trend simultaneously. Posts with the hashtags continued throughout the early days of June, and then tapered off. \#WhiteLivesMatter had a total of $811.3 \mathrm{k}$ posts on Twitter from $775.3 \mathrm{k}$ users, with a reach of a 761.8 million audience during the month of June. Although these hashtags were started by white supremacists, they were not dominated by them. As previously mentioned under the "Understanding K-pop Twitter" heading, a strategy K-pop fans use to get views on their fancams is by posting them along with a trending hashtag. K-pop fans are typically tweeting fancams with any trending hashtag, but what was surprising was that they had almost completely drowned out the white supremacists that had originally started it, therefore rendering the hashtags useless for their original intent. Examples of such tweets include one from @imasurvivor66 on June 2nd, stating, "I will see you all tomorrow for \#WhiteOutWednesday and \#WhiteLivesMatter Get it trending," and @ PoliteDerelict on June 3rd, "I've been mugged twice, once by a black guy and once by a group of blacks. I've had my house broken into once. Any guesses on the guy's race? \#WhiteLivesMatter \#WhiteOutWednesday \#ItsOkayToBeWhite". Most of the tweets seen under these hashtags from Twitter search were K-pop related. In fact, there were so many K-pop fans tweeting fancams, that Twitter had categorized the hashtags under "kpop" instead of "politics", or "current events", as shown in figure 3, taken from a tweet by user@My_Meatloaf.

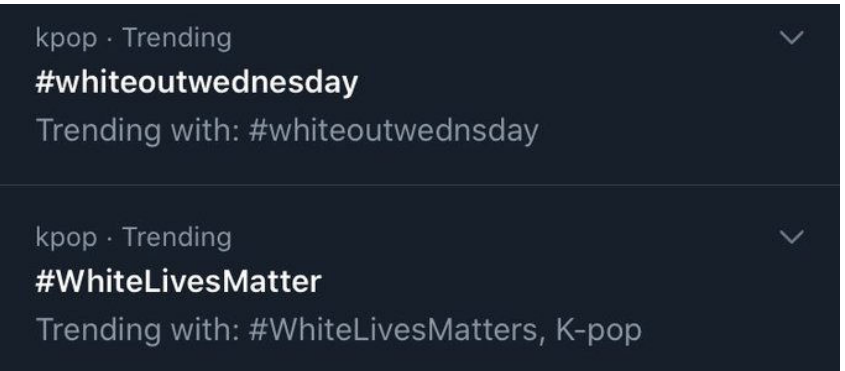

Figure 1. Hashtags categorized as K-pop

Source: @My_Meatloaf on Twitter.

Along with fancams, K-pop fans tweeted their contempt for racism. Figures 4 and 5 are among many similar tweets, ridiculing white supremacists. 


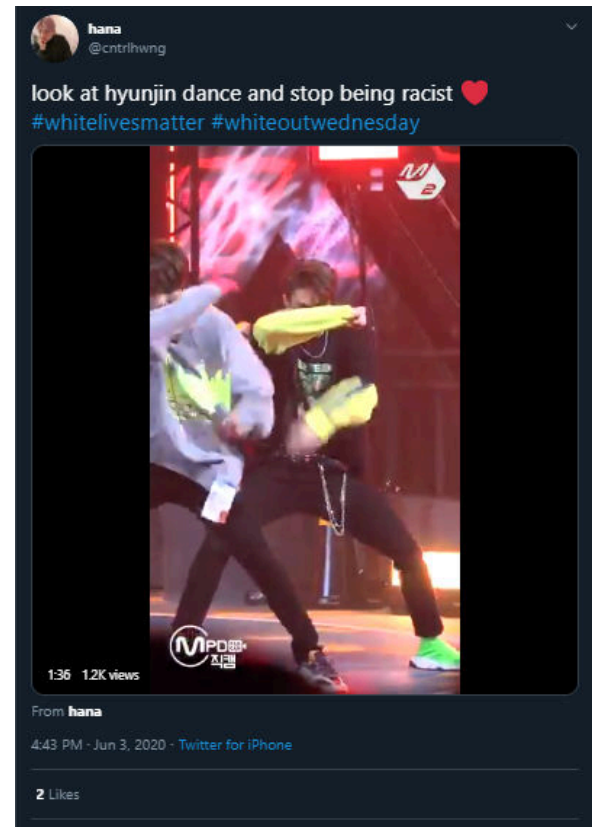

Figure 2. Fancam 1

Source: Twitter search.

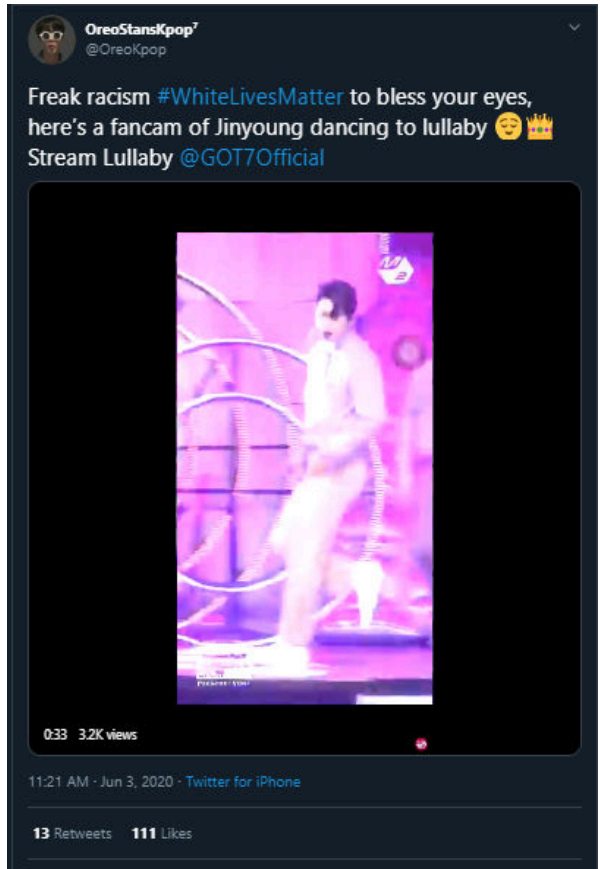

Figure 3. Fancam 2

Source: Twitter search.

Users began to notice how Twitter had labeled the hashtags as "kpop", and then began tweeting 
their thoughts on K-pop fans. By that time, the hashtags' original purposes were rendered useless, as the only tweets you could see were K-pop related. In addition to the intended impact of preventing white supremacists from gathering, this event also became a national news story. From Good Morning America, to Rolling Stone magazine, and NBC, the media reported on the uniting of K-pop fans to take over racist hashtags (Chan, 2020; Variety, 2020).

\section{Case Study: Pranking the Trump Campaign}

The final case study is the "sabotaging" of President Donald Trump's rally in Tulsa, Oklahoma. This was Trump's first rally after an extended hiatus due to COVID-19, so it was important to his campaign to recreate the crowds of supporters he previously enjoyed. Originally scheduled for Juneteenth, the rally was pushed back to June 20th, 2020. According to the Trump campaign, there were over 1,000,000 ticket requests. Even at 800,000 ticket requests, it promised to be the biggest planned rally Trump had ever had. On June 14th, Trump's campaign manager, Brad Parscale tweeted "Just passed 800,000 tickets. Biggest data haul and rally signup of all time by 10x. Saturday is going to be amazing!" The venue only held 19,000 seats, thus a large overflow area was built outside of the stadium. However, even before the rally began, the overflow area was already being dismantled. As stated by the Tulsa Fire Department, fewer than 6,200 people showed up, which the Trump campaign denied (Nobles, 2020). This humiliating prank on the President was credited to Generation Z, specifically Tiktok users and K-pop fans. The original Tiktok video calling attention to the mass ticket requesting was posted by user@maryjolaupp on June 11th. In it, she states:

"Somebody on another Tiktok post commented that he [Trump] was offering two free tickets on his campaign website to go to this rally, so I went and investigated it. It's two free tickets per cellphone number. Because when you register, you have to give them your cell phone number, they send you a code, you put the code in, and your tickets are reserved for you... So, I recommend all of those of us that wanna see this 19,000-seat auditorium barely filled or completely empty, go reserve tickets now, and leave him standing there alone on the stage. Whaddya say?"

The video has since gotten over 2.1 million views, $719.8 \mathrm{k}$ likes, and $139.1 \mathrm{k}$ shares. Incidentally, the Biden campaign had gotten word of her video, and offered her a job. After the message of the video was heard, many teens posted videos of them reserving tickets, often under fake names, as seen in figures 4 and 5. The teen in figure 4 quotes the 2004 movie "Mean Girls", by pretending to cough, and saying that she "can't go because [she's] sick". The teen in figure 5 dances over a screenshot of the ticket reservation form, with the tickets reserved under the notable name of Jeffery Epstein. 


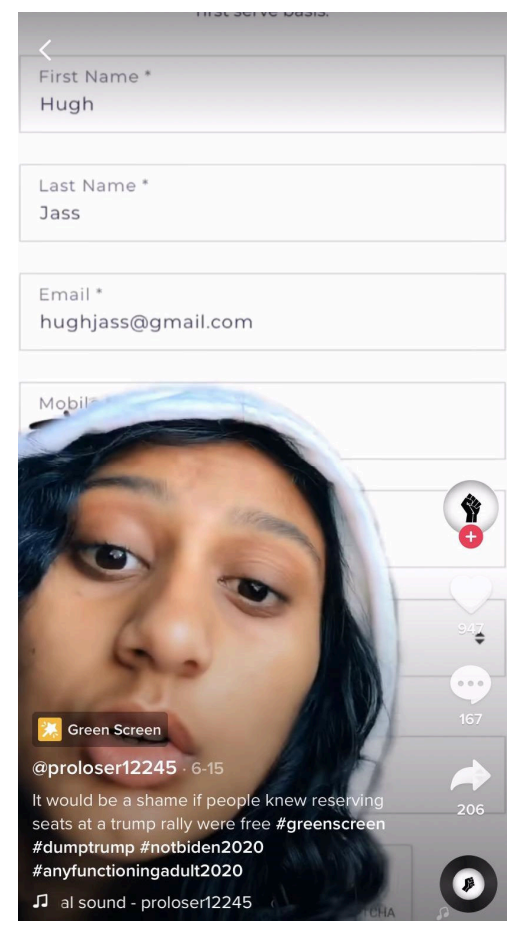

Figure 4. Teen reserving tickets

Source: @proloser12245 on Tiktok.

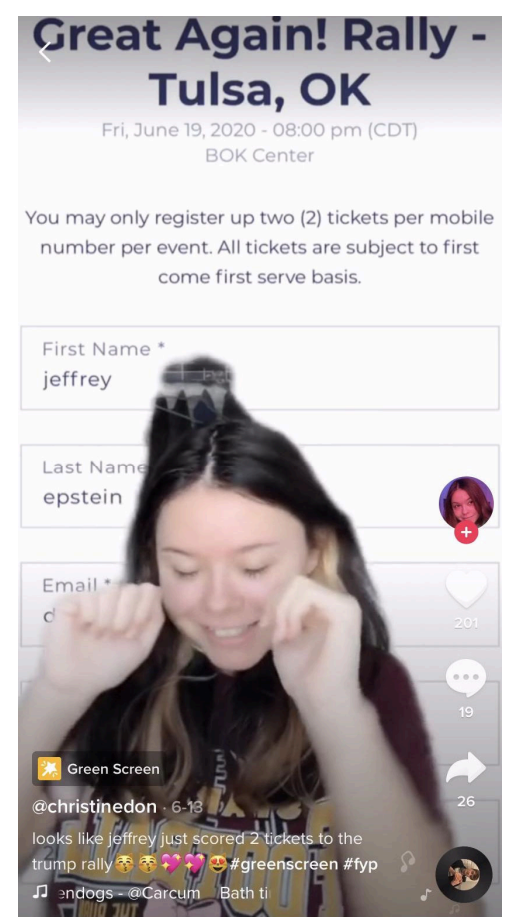

Figure 5. Another teen reserves tickets

Source:@christinedon on Tiktok. 
After the rally, K-pop fans and Tiktok teens were quick to take credit for the low turnout, and the media was also quick to give it to them. This event became a top news story, as news reports and video focused on the vast sea of empty seats. For example, an article by the New York Times entitled, "TikTok Teens Tank Trump Rally in Tulsa, They Say", was published on June 21 st. Adding to the ridicule, many late-night comedians used the story for their segments. On June 20th, Steve Schmidt, a Republican campaign strategist tweeted, "This is what happened tonight. I'm dead serious when I say this. The teens of America have struck a savage blow against@realDonaldTrump. All across America teens ordered tickets to this event. The fools on the campaign bragged about a million tickets. lol..." Many tweets then were posted thanking both the K-pop fans, and teenagers on Tiktok.

\section{Discussion}

These case studies demonstrate a form of political activism that is uniquely characteristic of Gen Z. In fact, we have never seen this type of activism performed in prior generations. Gen Z was raised with social media, as opposed to their predecessors. Gen $Z$ has been using social media since childhood, so it is only natural that their styles of political activism will develop as technology does, as well. The types of digital activism presented in this paper can be categorized based on their level of effort, and level of impact.

Table 1. Activism by level of effort and impact

\begin{tabular}{lll}
\hline & Low Impact & High Impact \\
\hline Low Effort & Signing or creating an online petition & Spamming tweets on a hashtag \\
& Pranking a campaign & Crashing a website or an app \\
\multirow{3}{*}{ High Effort } & Writing a letter to the editor & Voting \\
& Attending a rally & Protesting \\
\hline
\end{tabular}

Table 1 categorizes each example of activism, both conventional and non-conventional, that has been specified or will be specified in this paper. Beginning with the three case studies, the crashing of the police app has been categorized as low effort, and high impact. It requires less effort than voting and protesting, which demand a physical presence. Its impact is also higher than that of signing an online petition, as many petitions circulating around the internet do not have any real-world impact (though many are symbolic). The two police apps had been temporarily shut down due to the overload of fancams uploaded, and the identities of the protesters were protected, thus preventing police from making any arrests. The second case study, the drowning out of white supremacists on Twitter, has been categorized as low effort, but a high impact. Sending a tweet with a hashtag takes little to no effort, much less than writing a letter to the editor of a newspaper, but its impact is higher. By spamming the racists' hashtags, which the racists used to organize, those hashtags were rendered useless. White supremacists were practically unable to communicate through \#WhiteOutWednesday, and \#WhiteLivesMatter. The final case study, the sabotaging of Trump's Tulsa rally, is low effort, and low impact. As previously mentioned in the third case study, the rally had originally 
accommodated for an overflow crowd. However, it was dismantled before the rally began, because there was nobody there. Although many teenagers on Tiktok and K-pop fans requested tickets, if there were people that wanted to attend, but did not have a ticket, they could have been in the overflow area. This is categorized as low impact, because the mass requesting of tickets did not sabotage the rally itself, rather, humiliated the Trump Campaign. I refer to this event as a "prank" on the table, as that is, in essence, what it was.

Aside from the three case studies, I have included more examples of activism, and where they would fall on the table. Writing a letter to the editor of a newspaper requires a higher amount of effort than signing an online petition, but has a lower impact than spamming tweets on Twitter. In the same category, high effort and low impact, attending a rally is also included. It requires more effort than pranking a campaign, as you can do that without physically going anywhere, but its impact is lower than protesting. I have categorized voting as high effort and high impact, because of the inordinate number of barriers placed on voters in the United States. There is a growing trend toward hours long lines for in person voting, and difficulty in receiving mail ballots (Litt, 2020; Austin-Hillery, 2020). Protesting also falls under high effort and high impact. While some examples of protests, such as small neighborhood ones could be categorized as low effort and low impact, historically, protesting is high effort and high impact. Protesters risk being in danger, and even being killed (Narayan, 2017).

As we have seen, some modes of activism are associated with different generations. Members of the Baby Boomer generation would be more inclined to write letters to newspaper editors than Millennials, and members of Gen $Z$ would be more likely to post on social media than Gen $X$. As shown in Figure 6, posting on social media has a higher impact than writing letters to editors. This is because, as mentioned previously, activism evolves with both technology and time. Activism itself can be thought of as a continuum, which is constantly growing and changing. Currently, young people tend to participate less in conventional activism, and favor digital activism, because there is an option. Whereas when members of the Baby Boomer generation were younger, the proper technology for digital activism had not been invented yet. As Gen $\mathrm{Z}$ ages they may be more likely to value digital activism, as well as conventional activism, as the life cycle effect theory states that political participation increases with age. An interesting avenue for future research would be to analyze the role of digital activism in relation to conventional activism as Gen $\mathrm{Z}$ matures.

\section{Conclusion}

As digital activism was part of Gen Z's political awakening, the generational effects theory would suggest that they continue to practice this as a habit as they mature in age. It would be interesting to study the extent to which Gen $\mathrm{Z}$ continues digital activism, or changes their modes of activism as they age. Future research could also continue to follow the political development of Gen $\mathrm{Z}$ on social media, as well as take note of new forms of social media as they emerge. Studies on the impact of social media on politics will be important to current and future generations, as both technology and times change. Activism is constantly evolving, so the notion that a newer form of it is not real activism is misguided. Through analyzing the level of effort and impact of different examples of activism, I have concluded that digital is just as 
impactful as conventional.

\section{References}

Aldrich, J. H., Carson, J. L., Gomez, B. T., \& Rohde, D. W. (2020). Change and continuity in the 2016 and 2018 elections. Los Angeles, California: SAGE/CQ Press.

Austin-Hillery, O. (2020, April 26). Amid the pandemic, the right to vote is a life and death issue. $\quad$ Retrieved July 09, 2020, from https://www.cnn.com/2020/04/26/opinions/vote-rights-pandemic-covid-19-austin-hillery/inde $\mathrm{x} . \mathrm{html}$

Braungart, R. G., \& Braungart, M. M. (1986). Life-Course and Generational Politics. Annual Review of Sociology, 12(1), 205-231. https://doi.org/10.1146/annurev.so.12.080186.001225

Chan, T. (2020, June 03). K-Pop Power: Fandoms Unite to Take Over \#WhiteLivesMatter Hashtag on Twitter. Retrieved July 09, 2020, from https://www.rollingstone.com/music/music-news/white-lives-matter-k-pop-1009581/

Cho, A., Byrne, J., \& Pelter, Z. (2020). Digital civic engagement by young people. UNICEF report. Retrieved from https://www.unicef.org/globalinsight/reports/digital-civic-engagement-young-people

CNN. (2019, August 17). American Generation Fast Facts. Retrieved July 11, 2020, from https://www.cnn.com/2013/11/06/us/baby-boomer-generation-fast-facts/index.html

De Choudhury, M., Jhaver, S., Sugar, B., \& Weber, I. (2016). Social Media Participation in an Activist Movement for Racial Equality (pp. 92-101). Proceedings of the International AAAI Conference on Weblogs and Social Media. International AAAI Conference on Weblogs and Social Media.

Fieldhouse, E., Tranmer, M., \& Russell, A. (2007). Something about young people or something about elections? Electoral participation of young people in Europe: Evidence from a multilevel analysis of the European Social Survey. European Journal of Political Research, 46(6), 797-822. https://doi.org/10.1111/j.1475-6765.2007.00713.x

George, J. J., \& Leidner, D. E. (2019). From clicktivism to hacktivism: Understanding digital activism. Information and Organization, 29(3). https://doi.org/10.1016/j.infoandorg.2019.04.001

Holbein, J. B., \& Hillygus, D. S. (2015). Making Young Voters: The Impact of Preregistration on Youth Turnout. American Journal of Political Science, 60(2), 364-382. https://doi.org/10.1111/ajps.12177

Jenkins, H. (2019). Youth Voice, Media, and Political Engagement: Introducing the Core Concepts in By Any Media Necessary (Edited by Henry Jenkins, Sangita Shresthova, Liana Gamber-Thompson, Neta Kliger-Vilenchik, \& Arely M. Zimmerman). New York: NYU Press.

Keller, J. M. (2012). Virtual Feminisms. Information, Communication \& Society, 15(3), 429-447. https://doi.org/10.1080/1369118X.2011.642890 
Kristofferson, K., White, K., \& Peloza, J. (2014). The Nature of Slacktivism: How the Social Observability of an Initial Act of Token Support Impacts Subsequent Prosocial Action. PsycEXTRA Dataset. https://doi.org/10.1037/e509992015-078

Litt, O. (2020, July 06). Long voting lines threaten our democracy. Fixing them is easier than you think. Retrieved July $09, \quad 2020$, from https://www.cnn.com/2020/06/23/opinions/fixing-long-voting-lines-litt/index.html

Marketplace Tech. (2020, June 2). Police can track protesters even after the demonstrations end. Retrieved July 10, 2020, from https://www.marketplace.org/shows/marketplace-tech/police-protesters-surveillance-trackingfacial-recognition/

Miller, B. (2020, June 16). Police using facial recognition software to identify protesters, civil rights advocates claim. Retrieved July 09, 2020, from https:/www.wpxi.com/news/washington-news-bureau/police-using-facial-recognition-softwa re-identify-protesters-civil-rights-advocates-claim/5X5L2TGCLRF6JBHEYC3ABKQMIU/

Mohsin, M. (2020, July 03). 10 TikTok Statistics That You Need to Know [May 2020]. Retrieved July 09, 2020, from https://www.oberlo.com/blog/tiktok-statistics

Morozov, E. (2009, May 19). The brave new world of slacktivism. Retrieved July 09, 2020, from https://foreignpolicy.com/2009/05/19/the-brave-new-world-of-slacktivism/

Narayan, C. (2017, December 16). Heather Heyer died 'fighting for what she believed in'. Retrieved July 09, 2020, from https://www.cnn.com/2017/08/13/us/charlottesville-heather-heyer-profile/index.html

Nobles, R. (2020, June 21). Tulsa official says 6,200 attended Trump rally as campaign tries to blame 'radical' protesters and media for lack of crowd. Retrieved July 09, 2020, from https://www.cnn.com/2020/06/21/politics/trump-rally-tulsa-attendance/index.html

Plutzer, E. (2002). Becoming a Habitual Voter: Inertia, Resources, and Growth in Young Adulthood. American Political Science Review, 96(1), 41-56. https://doi.org/10.1017/S0003055402004227

Variety. (2020, June 03). K-pop fans take over \#whitelivesmatter hashtag. Retrieved July 09, 2020 , from https://www.nbcnews.com/news/asian-america/k-pop-fans-take-over-whitelivesmatter-hashta g-n1223376

Yang, G. (2016). Narrative Agency in Hashtag Activism: The Case of \#BlackLivesMatter. Media and Communication, 4(4), 13. https://doi.org/10.17645/mac.v4i4.692

Notes

Note 1. As defined by CNN, the generations are: Baby Boomer (1946-1964), Generation X (1965-1980), Millennials (1981-1996) and Gen Z (1997-2012). 
Note 2. Additional tweets used in this analysis can be viewed in the Appendix.

Note 3. All tweets taken from Twitter search.

\section{Appendix A}

\section{Additional Tweets used for Research (Note 3)}

(From left to right) Tweet thanking K-pop fans for flooding racist hashtags, user recognizes K-pop fans' and Gen Z's efforts, K-pop fan tweeting about uploading a video onto the iWatch app, user observes K-pop fans' work, K-pop fan reserving tickets for Tulsa rally, another K-pop fan jokes about not attending the rally after requesting tickets, K-pop fan denouncing racist hashtags with a fancam, user participating in \#WhiteoutWednesday

Kathryn Straub

@KathrynStraub1

I love the Kpop kids so much. Word is they were behind the movement of teens to purchase mass tickets for the Trump Rally. They also routinely hi jack right extremists hashtags. \#Thankyoukpop

4:57 PM . Jun 20, 2020 . Twitter for iPhone

4 Likes

\section{Unpearable Papa
@jonislike}

so kpop fans and gen z secretly registered for thousands of trump rally tickets to make it seem like it was gonna be record attendance looooool

4:40 PM - Jun 20,2020. Twitter for iPhone

12 Retweets and comments 97 Likes

\section{yangyang bi}

dallas police dept i hope u enjoy my yuta fancam bitch $<3$

3:33 PM - May 31, 2020 - Twitter for Android

\section{(8) sam}

seriously the \#WhiteLivesMatter hashtag trending right now is absolutely amazing. racists have been drowned out in a flood of posts by anti-racist kpop fans $\theta$ 1:41 PM . Jun 3, 2020 . Twitter for iPhone

5 Likes 


\section{MInstitute ${ }^{\text {Macrothink }}$}

International Journal of Social Science Research ISSN 2327-5510 2021, Vol. 9, No. 2

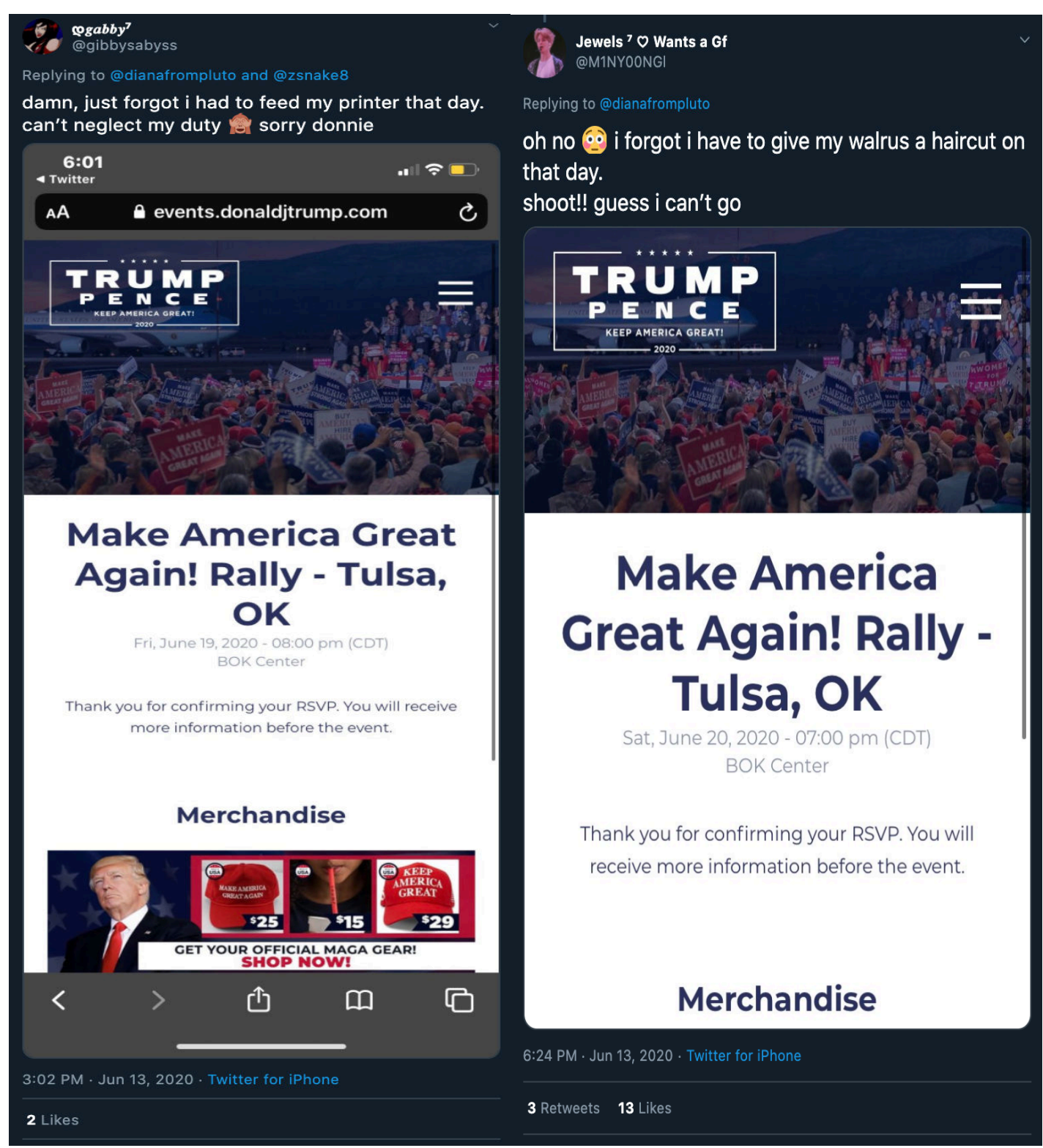




\section{Macrothink}

International Journal of Social Science Research ISSN 2327-5510 2021, Vol. 9, No. 2

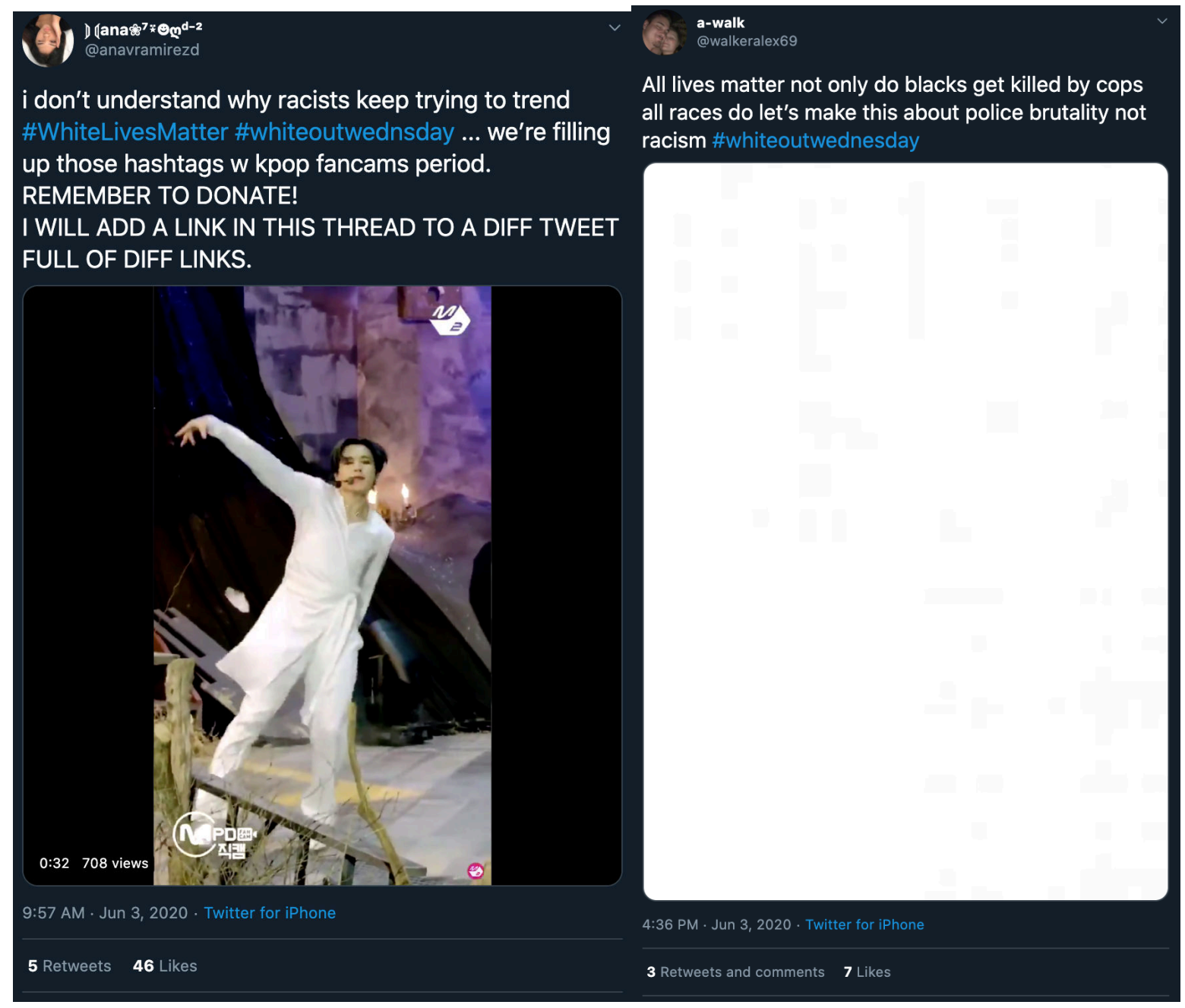

\section{Copyrights}

Copyright for this article is retained by the author(s), with first publication rights granted to the journal.

This is an open-access article distributed under the terms and conditions of the Creative Commons Attribution license (http://creativecommons.org/licenses/by/4.0/). 